DOI: $10.53425 /$ madergisi.989297

Araştırma Makalesi-Research Article

\title{
TÜRK MİLLIYYETÇİLİĞİ MİZAH ÜRETEBİLİR Mİ? ÇAYLAK DERGİSİ ÖRNEĞİ (1976-1978)
}

Cem Ozan AVCI*

\begin{abstract}
ÖZ: Mizah dergileri, hayata farklı bir bakış açısıyla bakabilen, toplumun nabzını tutabilen dergilerdir. Bu tür dergilerde sivri dil ve iğneleyici ifadelerle topluma, gündelik hayata, yaşanan siyasal, sosyal, ekonomik gelişmelere eleştiriler getirilmektedir. Politik mizah da belirli bir siyasal zaviyeden iktidara, muhalefete, siyasal sisteme yöneltilen eleştirilerden ortaya çıkmaktadır. Türk mizah yayıncılığının ilk dergisi 1852 yılında yayımlanan Boşboğaz Bir Adem isimli dergi olmakla birlikte günümüze kadar Diyojen, Akbaba, Girgır, Tef, Uykusuz gibi yüzlerce mizah dergisi yayımlanmıştır. Çaylak dergisi ise Ülkücü Hareketin ideolojik sınırları çerçevesinde 1976-1978 yılları arasında 27 sayı yayımlanmış bir mizah dergisidir. Bu makalede öncelikle mizah kavramı kısaca irdelenecek, daha sonra ana hatlarıyla Türk kültüründe mizah, Türkiye'de mizah yayıncıllı̆ı ve Türkiye'de milliyetçi dergiler incelenecektir. Son bölümde ise Çaylak dergisi hakkında genel bilgiler verilecek, derginin ortaya çıkış sürecinden bahsedilecektir. Dergideki içerik derginin neşredildiği dönemdeki siyasi ortamdan Nejat Uygur'a kadar 10 farklı başlık altında gruplandırılmak suretiyle aktarılacak, Türk milliyetçiliğinin mizah üretip üretemeyeceğine dair cevap aranacaktır.
\end{abstract}

Anahtar Kelimeler: Mizah, Politik Mizah, Çaylak Dergisi, Türk Milliyetçiliği, Ülkücü Hareket.

* Doktora Öğrencisi, Ankara Hacı Bayram Veli Üniversitesi, Siyaset Bilimi ve Kamu Yönetimi Anabilim Dalı, cem.avci@hbv.edu.tr, ORCID: 0000-0002-96631194. 


\title{
CAN TURKISH NATIONALISM PRODUCE HUMOR? ÇAYLAK MAGAZINE EXAMPLE (1976-1978)
}

\begin{abstract}
Humor magazines are those who can look at life from a different perspective and keep their deep pulse. In such magazines, criticism is brought to society, daily life, political, social, and economic developments with sharp tongue and sarcastic expressions. Political humor also emerges from the criticisms directed at the government, the opposition, and the political system from a certain political point of view. Although the first magazine of Turkish humor publishing was Boşboğaz Bir Adem, published in 1852, hundreds of humor magazines such as Diyojen, Akbaba, Gırgır, Tef, Uykusuz have been published until today. Çaylak Magazine, on the other hand, is a humor magazine that was published in 27 issues between 1976-1978 within the framework of the ideological boundaries of the Nationalist Movement. In this article, firstly, the concept of humor will be briefly examined, then humor in Turkish culture, humor publishing in Turkey and nationalist magazines in Turkey will be examined. In the last part, general information about Çaylak magazine will be given and the emergence process of the magazine will be mentioned. The content in the magazine will be grouped under 10 different titles, from the political environment at the time the magazine was published to Nejat Uygur, and an answer will be sought as to whether Turkish nationalism can produce humor.
\end{abstract}

Keywords: Humor, Political Humor, Çaylak Magazine, Turkish Nationalism, Nationalist Movement.

\section{GİRIŞ}

Mizah, Arapça'da "şaka ve latife yapmak" anlamina gelen mezh kökünden dilimize geçmiş olup TDK tarafından "gülmece" olarak tanımlanmaktadır (www.tdk.gov.tr). İslam Ansiklopedisinde ise "Edebiyatta düşünceleri espri ve nükteyle süsleyerek anlatan söz ve yazı çeşidi" olarak ifade edilmiştir (islamansiklopedisi.org.tr). Mizah anlatılmak istenilen düşünceleri, kanaatleri nüktedan bir biçimde anlatmak, insanları düşünmeye sevk etmek amacıyla ortaya çıkmış bir sanattır. Mizah insan davranışında gülmeyi, güldürmeyi 
ortaya çıkarmaktadır. Güder de (2012: 4) mizahın insanları güldürmekten ziyade eleştirel düşünmeye, muhalif tutuma ve olaylara farklı açılardan bakabilmeye sevk ettiğini ifade etmiştir.

Mizahın latife, nükte, şaka, iğne ve taş, hiciv, alay ve halt olmak üzere yedi farklı çeşidi bulunmaktadır. Bu kavramlar birbirine yakın kavramlar olmakla birlikte küçük nüanslarla birbirlerinden ayrılmaktadırlar. Latife üslup olarak daha yumuşak bir muhtevaya sahipken, nükte ince manalar içermektedir. İğne ve taş kelime oyunları ile yapılan yermelere verilen isimdir. Hiciv suçlamaya çok yakın bir yerde durmakta ve karşısındakine saldırı işlevi bulunmaktadır. Alayda fark ettirmeden karşıdaki övülmektedir. Halt ise münasebetsiz bir söz söylemek olarak tanımlamakta ve dilimize de "halt etmek" olarak da yer almaktadır.

Mizahın popüler mizah, kara mizah ve politik mizah olmak üzere üç farklı türü bulunmaktadır. Popüler mizah, popüler olanı ele almakta, popüler kültürden beslenmektedir. Popüler kültür değişkenlik gösterdiğinden hızlı değişmektedir. Kara mizah ölüm, savaş veya hastalık gibi ciddi konuların mizahi açıdan ele alınmasıyla ortaya çıkmaktadır. Güldürmekten daha çok eleştirmeyi ve düşündürmeyi amaçlamaktadır. Politik mizah ise siyasi kişi, kurum, olayları ve toplumu ele almaktadır (Çavdar, 2018: 47).

Teknolojinin gelişmesiyle birlikte mizah anlayışında da değişim ve dönüşüm yaşanmıştır. Yazılı basının ortaya çıkmasıyla sözlü basının önemi azalırken mizah açısından da çeşitlilik ortaya çıkmıştır. Mizah sözlü olarak fıkralar, tekerlemeler, meddah gösterileriyle ortaya konarken süreç içerisinde yazılı mizah ortaya çıkmış ve mizah üretenler yazar ve çizer olarak ikiye ayrılmıştır. Sözlü mizah döneminde ortada hiç yokken yazılı mizah dönemiyle birlikte karikatür ortaya çıkmış ve mizahın en güçlü silahı olarak başköşeye oturmuştur (Öngören, 1998: 22).

Karikatür Rönesans'la birlikte İtalya' da ortaya çıkmış olup o dönemdeki adı "caricaredir" Caricare hücum etmek anlamına gelmektedir. Zaman içinde hücum etmek yerini "eleştiriye" bırakmıştır. Karikatür sanatsal bir çıtı almak, mizah yoluyla toplumları 
iyiye yönlendirmek amacını taşımaktadır (Şenyapılı'dan akt. Çavdar, 2018: 50). Karikatür vasıtasıyla sınırlı sayıda sözcük ve çizgiyle normalde yapılamayacak eleştiriler yapılabilir hale gelmektedir. Temel amacı güldürü olmakla birlikte haber verme, eğlendirme, eğitim, tabuları ve mitosları yıkma, karşı çıkma, estetik kaygı ve reklam gibi amaçları da bulunmaktadır (Topuz'dan akt. Çavdar, 2018: 52).

\section{POLITIIK MIZZAH}

Politik mizahtan en çok iktidarlar olmakla birlikte siyasal alanda bulunan herkes, her şey nasibini almaktadır. Yasaklanan, engellenen her şey, siyasi karakterler, siyasi olaylar politik mizahın konusu olabilmektedir. Özellikle diktatörlerin, baskıcı rejimlerin olduğu ülkelerde politik mizah yoluyla şiddet içermeyen bir direniş yaratılabilmektedir. Politik mizah ile siyasal partilerin, siyasetçilerin ürettiğinden daha güçlü bir eleştiri üretilebilmektedir. Bu bağlamda politik mizah güçlü bir silahtır.

Politik mizahın ilk görünümlerine Atina demokrasisinde rastlanılmaktadır. $\mathrm{O}$ dönemde rejimi eleştiren ve mizahtan beslenen pek çok teatral gösteri ve şiir bulunmaktadır (Henderson'dan akt. Türk, 2015: 14). Yine 18. yüzyllda İngiltere' de Hannover hanedanıyla Jakobitler arasında yaşananları anlatan çizimler önemli politik karikatürlerdendir (Çavdar, 2018: 47).

Ayrıca politik açıdan yazılı olarak eleştiri getirilemediği durumlarda sözlü geleneğe de başvurulmaktadır. Sözlü politik mizah daha çok baskıcı rejimlerin olduğu ülkelerde kendini göstermektedir. Politik özgürlüklerin kısıtlandığı ülkelerde politik mizah protestonun en önemli enstrümanlarından birisidir. Çarlık Rusya, komünist Doğu Avrupa ve Mısır gibi ülkelerde pek çok örneği bulunmaktadır. Özellikle Mısırlılar için sözlü politik mizah geleneğinin yeri oldukça büyüktür. Hatta Misırlılara "ibn nukta” yani şakanın çocukları denilmektedir. Cemal Abdülnasır, Enver Sedat ve Hüsnü Mübarek gibi isimler üzerinden üretilen politik fıkralar, Mısırlıların bu isimlere yönelik ciddi tepkilerini yansıtmaktadır (Güder, 2012: 24). 
Her ne kadar siyasi partiler, liderler hoşlanmiyor olsa da günümüzde politik mizahın en güçlü enstrümanını karikatürler oluşturmaktadır. Karikatürlerin siyasi iktidarın zayıf yönlerini alaycı bir üslupla ele almaları siyasileri rahatsı etmektedir. Siyasiler toplum nezdinde küçük düşürüldüklerini, siyasi hareketlerinin zarar gördüğünü düşünmektedirler. Bu sebeple dünyanın pek çok yerinde bu kapsamda yapılan yayınlar yasaklanmış, karikatüristler cezalandırılmıştır.

Ancak siyasi amaç ve hedeflerle etik değerlerden uzak, insanların kutsallarıyla alay eden, dini inançlara ve kimliklere saldıran ırkçı karikatür çizimleri de olmuştur. Örneğin İran'da 12 Mayıs 2006 tarihinde yayımlanan bir devlet gazetesinde İran'da yaşayan ve nüfus içinde önemli bir çoğunluk olan Azerbaycan Türklerine yönelik olarak hamam böceği benzetmesi yapılmıştır. Bu karikatürden sonra Azerbaycan Türklerinin yoğunlukla yaşadığı bölgelerde büyük olaylar yaşanmış, onlarca kişi hayatını kaybetmiştir. Yine Hz. Muhammed'i hedef alan karikatürler 30 Eylül 2005 tarihinde Danimarka'da Jyllands-Posten dergisinde, 2 Eylül 2020 tarihinde ise Fransa'da Charlie Hebdo dergisinde yayımlanmış ve İslam dünyasinda büyük infial uyandırmıştır.

Türkiye' de de 1990'lı yıllarda renkli televizyonların yaygınlaştığ1 döneme kadar politik mizah önemli bir yer edinmiştir. Alpaslan Türkeş, Bülent Ecevit, Necmettin Erbakan, Tansu Çiller, Süleyman Demirel, Deniz Baykal, Mesut Yilmaz gibi siyasi liderler pek çok kez karikatürize edilmiş, mizah dergilerinde yer bulmuşlardir.

\section{TÜRK KÜLTÜRÜNDE MIZAH}

Mizahın Batı kültüründe ve Batı edebiyatında olduğu kadar Türk kültüründe ve edebiyatında da önemli yeri bulunmaktadır. Yazılı eserlerde, halk hikâyelerinde mizahın önemli görünümleri bulunmaktadır. Türkçe'nin bilinen en eski sözlüğü olan ve Kaşgarlı Mahmut tarafından kaleme alınan Divan-ı Lugatit Türk'te bizatihi "mizah" kavramı geçmiyor olsa da gülmek alay etmek kavramına gelen kelimeler kullanılmıştır. Bunlar yüz açukluğu (yüz gülümseyişi), elük (alay etme), katgurmak (gülerek katılmak), köğ (gülmece) 
gibi kelimelerden oluşmaktadır (Alay, 2019: 23). Bu kelimeler Türk kültürel belleğinde çok eski dönemlerinden itibaren mizahın kullanıldığını göstermektedir. Yine Türk tarihinin eski dönemlerinde Türkistan'da düzenlenen şölenlerde, halk hikâyelerinde, mitolojide, yazılı metinlerde mizaha dair birçok unsur bulunmaktadır (Veren, 2018: 122).

Türklerin Anadolu serüveninde ise mizaha dair ilk örnekler Selçuklu döneminde karşımıza çıkmaktadır. Keloğlan masalları, Dede Korkut hikâyeleri, Nasreddin Hoca hikâyeleri, Bektaşi fıkraları bu dönemde ortaya çıkmıştır. Osmanlı döneminde ise topluma yönelik eleştiriler getiren Karagöz, Meddah ve Ortaoyunu kahvehanelerde oynanmıştır. Bunlarla birlikte Halk ve Divan edebiyatında birçok mizahi metin ve hiciv şairleri bulunmaktadır. Tanzimat döneminde de Şinasi' nin Şair Evlenmesi, Namik Kemal' in Hirrename gibi eserleri önemli mizah metinlerindendir. Servet-i Fünun döneminde Cenap Şahabbettin ve Ahmed Rasim, II. Meşrutiyet Döneminde Peyami Safa, Ömer Seyfettin; Milli Mücadele döneminde ise Neyzen Tevfik, Refik Halit Karay gibi isimler önemli eserleriyle Türk mizahına katkıda bulunmuşlardır (Turhanlı, 2019: 10).

\section{TÜRKIYYE'DE MIZAH YAYINCILIĞI}

Türkiye' de mizah yayıncılığının dikkate değer bir gelişim süreci bulunmaktadır. İlk mizah dergisinin yayımlandığı 1852 yılından bugüne yaklaşık 170 yıllık süreçte yüzlerce dergi çıkmıştır. Türkiye' de mizah yayıncılı̆̆ına dair Turgut Çeviker, Ferit Öngören gibi kalemlerce nitelikli yayınlar yapılmıştır. Bu bölümde detaya girmeksizin kısaca Türkiye' de mizah yayıncılığının gelişiminden bahsedilecektir.

İlk mizah dergisi 1852 yılında Hovsep Vartanyan Paşa tarafından yayımlanan ve tek sayı olarak neşredilen Boşboğaz Bir Adem isimli dergidir. Daha sonra 1856 yılında Meğu, 1867 yılında Tohafi isimli dergiler yayınlanmıştır. İlk Türkçe mizah dergileri ise 1870 yılında yayımlanmaya başlamıştır. Bunlar; 14 Mayıs 1870 tarihinde Terakki gazetesinin ekinde yayımlanan ve aynı ismi taşıyan Terakki dergisi, 3 Eylül 1870 tarihinde Mehmet Tevfik tarafından Asır dergisinin eki olarak yayımlanan ve aynı ismi taşıyan Asır dergisi, bir 
diğeri ise 24 Kasım 1870 tarihinde Teodor Kasap tarafından yayımlanan Diyojen dergisidir. Diyojen diğerlerinden farklı olarak Türk basın tarihindeki ilk müstakil mizah dergisi olarak öne çıkmaktadır (Demirkol, 2017: 21). 1870'li yıllarda Çıngıraklı Tatar, Meddah, Çaylak gibi birçok mizah dergisi yayımlanmıştır. Ancak II. Abdülhamid'in 1878 yılında anayasayı askıya alması ve Mebûsan Meclisini kapatmasıyla yeni bir dönem başlamış ve mizah dergileri de II. Meşrutiyetin ilanına kadar yaklaşık 30 yıl yasaklanmıştır (Türk, 2015: 60).

II. Meşrutiyetin 23 Temmuz 1908 tarihinde ilanıyla birlikte oluşan ortamda mizah yayıncılığında da büyük artış olmuştur. Hemen bir hafta sonrasında Zıpır isimli bir dergi yayımlanmıştır. 1908 yılında İstanbul' da 40'tan fazla dergi yayımlanmıştır. Ancak İttihat ve Terakki döneminde mizah dergileri yeniden oluşan baskı ortamindan dolayı tekrar azalmaya başlamış, sayısı 1913 yılında bire kadar düşmüştür (Türk, 2015: 67).

Kurtuluş Savaşı döneminde İstanbul hükümetini destekleyen Aydede, Ankara hükümetini destekleyen Güleryüz gibi dergiler yayımlanmıştır. Kurtuluş Savaşı sonrasında Aydede dergisinin kapatılmış ve Yusuf Ziya Ortaç ve Orhan Seyfi Orhon tarafından 1922 yılında Akbaba dergisi yayımlanmıştır. Akbaba 1922 yılından 1977 yılına kadar 55 sene boyunca yayın hayatına devam etmiş olup en uzun süre yayımlanan mizah dergisi olmuştur.

Cumhuriyetin ilanıyla birlikte mizah dergiciliği anlayışında da değişim yaşanmıştır. Osmanlı döneminde daha çok Arap alfabesinin kaligrafik oyunlarla ve süslemelerle kullanılması suretiyle oluşturulan yazı resim birlikteliği Cumhuriyet döneminde yerini eskisinden farklı olarak Batılı anlayışla çizilen, uyandırdığg derinlik duygusuyla birlikte resmi andırmaktan uzak bir şekle bürünmüştür. Çizgiler ve yazılı anlatım yalınlaşırken, çizimde açıkça gösterilen şeyler yazıda yinelenmemiştir. Bu dönemde Türk karikatürcüleri, Türk okuyucusuyla yeni ve ortak bir mizah dili oluşturmuştur (Sipahioğlu'ndan akt. Kılıçer, 2015: 28).

1923 ile 1950 y1lları arasında Kalem, Akbaba, Karagöz, Papağan, Guguk, Kelebek, Yeni Kalem, Nasreddin Hoca, Köroğlu, Babacan ve Mar- 
kopaşa gibi birçok mizah dergisi neşredilmiştir. Bu dönemde yayınlanan dergilerin büyük çoğunluğu CHP hükümetine eleştiri getirememiştir. Ancak Markopaşa dergisi bu açıdan diğerlerinden ayrılmaktadır. Markopaşa'nın CHP'yi karşısına alan yayın politikası 1950 y1lında Demokrat Parti'nin iktidara geçmesinde büyük paya sahip olmuştur. Altmış bine yakın satış yaparak bu alanda adeta çı̆̆ır açmiştır (Ustadan akt. Boz, 2014: 150).

1950'li yıllarda yayınlanan dergilerden 41 Buçuk, Tef, Dolmuş, Taş, Karikatür Demokrat Parti yönetimine muhalifken, Akbaba iktidar yanında saf tutmuştur (Türk, 2015: 88). Bu dönemde de daha önce olduğu gibi karikatür dergilerinin üzerindeki baskı devam etmiştir. Turhan Selçuk, Recep Tahir Burak, Ferruh Doğan gibi isimler çizdikleri karikatürler sebebiyle yargılanmışlardır. Ancak bu dönemde mizah öykücülerinin oranı artmış, Aziz Nesin, Rıfat Ilgaz ve Haldun Taner gibi isimler ön plana çıkmıştır (Türk, 2015: 90).

1960'lı ve 1970'li yıllarda basım-yayın teknikleri teknolojik gelişmelerle birlikte gelişmiştir. 1962 yılında Aziz Nesin tarafından Zübük, 1964 yılında Bülent Şeren tarafından Pardon isimli dergiler neşredilmiştir. 1969 yılında Karikatürcüler Derneği kurulmuştur. Bu dernek tarafından 1974 yılında Uluslararası Nasreddin Hoca Karikatür Sergisi ve Yarışması düzenlenmiş ve 18 ülkeden yaklaşık 250 çizer katılmıştır. Akşehir' de gerçekleştirilmeye başlanan bu etkinlik, uluslararası ölçekte Avrupalı karikatüristlerin II. Abdülhamid devrinden bu yana Türkiye aleyhine çizdiği fesli karikatürlerin son bulmasını sağlamıştır. Dünya karikatürcüleri tarafından Akşehir'de antik bir mizah geleneğinin temsilcisi olan Nasreddin Hoca'nın manevi şahsiyetin huzurunda gerçekleştirilen bu yarışmadan ödül almak bir prestij haline gelmiştir (Öngören, 1998: 125).

Özellikle 1970'li yıllardan itibaren kırdan kente göçün hızlanması mizah dergilerinde işlenen konularında değişmesine sebebiyet vermiştir. Bu ortamda 1972 yılında Oğuz Aral tarafından Gırgır dergisi çıkarılmaya başlanmıştır. Gırgır dergisi o dönemde siyasi konulardan ziyade halkın yaşadığı geçim sıkıntısı, sosyal meseleler gibi sosyo-ekonomik birçok konu üzerine eğilmiştir (Boz, 2014: 150). Mizah dergiciliğinde şekil olarak da farklılığ başlatan dergi metin-çizgi dengesinin çizgi lehine kaydığı, konuşma balonlu bir 
formla okuyucunun karşısına çıkmıştır. Gırgır dergisi 60 bin tiraja ulaşan Markopaşa dergisinin neredeyse 9 kat fazla tiraja ulaşmış ve 500 bin baskı yapılmıştır. 1970'li yıllarda Gırgır dergisi ile birçok kez davalık olan Demirel, açtığı davalardan birisinin kazandıktan sonra Mizah bir yumruktur, kime ineceği belli olmaz diyerek aslında Türk siyasetinde mizahın gücünün bir yumruk haline geldiğini de itiraf etmiştir (Türk, 2015: 95).

12 Eylül 1980 tarihinde gerçekleştirilen askeri darbe sonrasinda partiler ve dernekler kapatılmış olup 1970 yılında Karikatürcüler Derneği ve Karikatür Müzesi de bu durumdan nasibini almıştır. Karikatürcüler Derneğinin düzenlediği Uluslararası Nasreddin Hoca yarışması 1987 yılına kadar gerçekleştirilememiştir. 1983 yılında gerçekleşen seçimlere kadar karikatür bir durgunluk dönemi geçirmiştir. Genel seçimlerden sonra 1975 yılında yayın hayatına başlayan Çarşaf ve 1976 yılında yayın hayatına başlayan Fırt gibi dergiler yayın hayatlarına devam etmişlerdir.

1980 sonrası uygulanan sosyo-ekonomik politikalar toplumun alışkanlıklarının da değişmeye başlamasına sebebiyet vermiş, müzik, edebiyat, sanat, kültür hayatı da derinden etkilenmiştir. 1980-1990 yılları arasında neşredilen mizah dergileri genel itibariyle Gırgır dergisinde ayrılanlarca çıkarılan dergiler olmuştur.

1990'lı yıllarla birlikte Türkiye'de medyanın değişmeye başladığı yıllar olmuştur. Özel televizyon kanallarının yayın hayatına başlamasıyla birlikte mizah dergilerinin tirajları \%80 oranında azalmış, mizah dergiciliğinin çehresi de değişmiştir (Turhanlı, 2019: 14). 1990-2000 yılları arasında mizah dergilerinin sayısı oldukça artmakla birlikte Leman dergisi diğerlerinden ayrılarak öne çıkmıştır.

2000'li yıllarda Türkiye'de mizahçılar çete, mafya, kaçakçı, kaset, tetikçi, özelleştirme gibi konularla ilgilenmiştir. Öngören karikatürcülerin malzemelerinin değiştiğini, artık haklıyı savunmak haksızı yermek gibi bir romantik anlayışla konulara yaklaşamayacakların belirtmiş ve Karikatürcüler ve mizahçılar, şimdi elinde bir büyüteçle ayak izlerini gözleyen polis hafiyesi gibi espri arıyorlar demiştir (Öngören, 1998: 112). 
2000'li y1llarda da Girgır, Leman, Penguen, Uykusuz gibi dergiler ön plana çıkmıştır. Gırgır 1972 yılında başlamış olduğu yayın hayatına 45 yıl sonra 2017 yılında; Penguen ise 2002 yılında başlamış olduğu yayın hayatına 15 yıl sonra 2017 yılında son vermiştir. Leman ve Uykusuz hala yayınlarına devam etmektedir. Ancak internetin ve sosyal medyanın hayatımızda daha çok yer elde etmesi mizah dergilerini de etkilemiştir. Bu süreçte mizah dergileri tirajların düşmesi, buna bağlı olarak maddi getirisinin azalması, telifler ve dağıtım için ödenen ücretler, kağıt ve baskı maliyetlerinin artması, basılı yayıncılığın azalarak internete kayması gibi süreçlerden kötü yönde etkilenmiştir.

Penguen çizerlerinden Semra Can vermiş olduğu bir mülakatta mizah dergilerinin yaşadığı bu süreçle şöyle ifade etmiştir:

\begin{abstract}
Çizerler, editörler küçük küçük otosansür uygulamaya başladı. Yöneticiler, çizerlerden daha dikkatli olmalarını talep etmeye başladı. Mizahın yapılabileceği alanlar daraltıldı. Charlie Hebdo saldırısı mizahçılar için bir korku unsuru oldu ve otomatikman bir otosansüre gidildi. Bu da tirajları vurdu. Okuyucu kaybetti mizah dergileri. Mizanpajı da çok çocuksu yöne evrildi. Gri, siyah ve beyaz renk ağırlıklı dergiler çocuk dergilerine benzemeye başladı. Mizahın içeriği de naifleşti. Muhalif kimliğini yitirmeye ve bazı şeylere dokunmamaya başladı. Iç̧erik ve görsel açıdan okuyucunun beklentisi karşılanamadı (Sarı, 2017).
\end{abstract}

\title{
4. MİLLIYYETÇİ DERGİLER
}

Türk milliyetçiliğini bir neşriyat hareketi olarak tanımlamak yanlış olmayacaktır. Dergiler açısında değerlendirildiğinde 1910 yılında çıkarılmaya başlanan Genç Kalemler ve 1911 yılında çıkarılmaya başlanan Türk Yurdu dergisinden günümüze kadar onlarca dergi neşredilmiştir. Türk Yurdu ilk döneminde Yusuf Akçura, Ziya Gökalp, Hamdullah Suphi, Sadri Maksudi Arsal gibi Türk milliyetçiliğinin öncülerinin yazılarını yayınlamıştır. Türk Yurdu yayın hayatına bugün de devam etmektedir. Bunun dışında 1922 yılında Diyarbakır' da Ziya Gökalp tarafından çıkarılan Küçük Mecmua, 1923 yılında çıkarılan Milli Mecmua, 1924 yılında çıkarılan Anadolu Mecmuası, 1931 yılında Hüseyin Nihal Atsız tarafından çıkarılan Atsız Mecmua, 1932 yılında çıkarılan Azerbaycan Yurt Bilgisi Mecmuası, 
1933 yılında Milli Türk Talebe Birliği tarafından çıarılan Birlik dergisi, yine 1933 yılında çıkarılan Orhun ve Çı̆̆ır, 1938 yılında çıkarılan Ergenekon dergileridir (Darendelioğlu, 1968: 70-76).

1941 yılında Bozkurt ve Çınaraltı, 1942 yılında Tanrıdağ, Millet, Doğu ve Gökbörü dergileri, 1943 yılında Orhun, Kopuz ve Verim dergileri, 1945 yılında Toprak, 1946 yılında Hareket, Türkçülük ve Özleyiş dergileri, 1947 yılında Kızılelma, Kürşad, Düven, Serdengeçti ve Altınışık dergileri, 1949 yılında Milli Birlik, 1950 yılında Komünizme Karşı Mücadele ve Bizim Türkiye, 1951 yılında Savaş, 1952 yılında Oğuz, Hareket, Gurbet ve Türk Dünyası, 1954 yılında Toprak, 1955 yılında Ocak ve Mücahit, 1954 yılında Türk Yolu, 1956 yılında Çakmak, 1960 y1linda Emel ve Yeni İstiklal, 1961 yılında Düşünen Adam, 1962 yılında Orkun ve Milli Yol, 1963 yılında Fedai, 1964 yılında Ötüken ve Milli Mücadele, 1965 yılında Yol, 1967 yılında Milli Işık gibi dergiler çıkarılmaya başlanmıştır (Darendelioğlu, 1968: 202-212, 367-375).

1966 yılında Milli Hareket, 1968 yılında Ocak ve Genç Ülkücüler teşkilatının yayın organı olan Milli Ülkü, 1969 yılında Töre ve Devlet, 1971 yılında Bozkurt, 1974 yılında Büyük Ülkü ve Ülkü-Tek, 1975 y1lında Genç Arkadaş, Hasret ve Ülkü-Bir, 1976 yılında Çaylak, Ülkücü Kadro ve Ülküm, 1977 y1lında Yiğit Köylüm ve Bizim Gergef, 1978 y1lında Divan, Milli Eğitim ve Kültür, Kutsal Alın Teri ve Nizam-ı Alem, 1979 yılında Kon, Ülkü Ocă̆ı ve Birliğe Çă̆rı gibi dergiler çıkarılmaya başlanmıştır. Yine bu dergilerin dışında Türkiye ve Dünya, Ananın Sesi gibi dergiler de yayımlanmıştır (Akpınar, 2005: 93-96).

1980 askeri darbesinden sonra 1980 yılında Yeni Sözcü, 1981 yılında Yeni Hizmet, 1983 yılında Bizim Ocak, 1993 yılında Ülkü Ocă̆ı gibi dergiler çıkarılmaya başlanmıştır.

Bugün Ülkü Ocağı, Türk Yurdu, Türk Dünyası Kültür ve Tarih, Ayarsız, Milli Mecmua, Çelebi, Toy, Genç Avaz, Bilge Türk, Söğüt, Kam Davulu, Onuncu Köy, Balta Dergi, Yeni Ufuk, Bozkır ve Demlik gibi birçok milliyetçi dergi neşredilmektedir.

1976 yılında çıkarılmaya başlayan Çaylak, tüm bu dergilerden farklı olarak mizah amacıyla çıkarılan tek dergi olarak göze çarpmaktadır. Bundan sonraki kısımda Çaylak dergisi değerlendirilecektir. 


\section{5. ÇAYLAK DERGİsi}

Ülkücü hareketin mizah dergisi olan Çaylak'ın ilk sayısı 1976 yılının haziran ayında son sayısı ise 1978 yılının mayıs ayında yayımlanmıştır. Son sayısı 26 ve 27 . sayıları birlikte yayımlanmak suretiyle çıkarılmıştır. Toplam 27 sayıdan ibarettir. Bu isimle Türkiye' de yayınlanan ikinci mizah dergisidir. Diğeri Çaylak Tevfik tarafından tam bir asır önce 1876-1877 yılları arasında çıkarılmıştır. Nitekim dergiye adının verildiği de ikinci sayıda Türk Mizah Ustaları başlı̆̆ı altında Çaylak Tevfik Bey anlatılırken ifade edilmiştir (Çaylak Dergisi; 1976: 8).

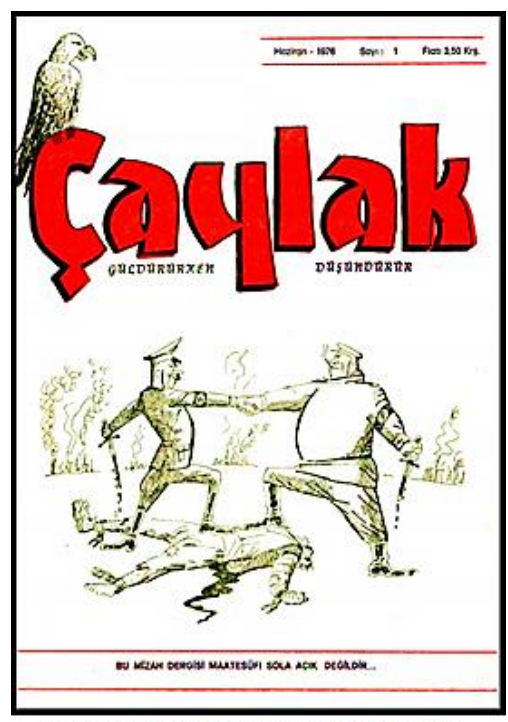

Resim 1: Çaylak Dergisi 1. Sayıı (1976)
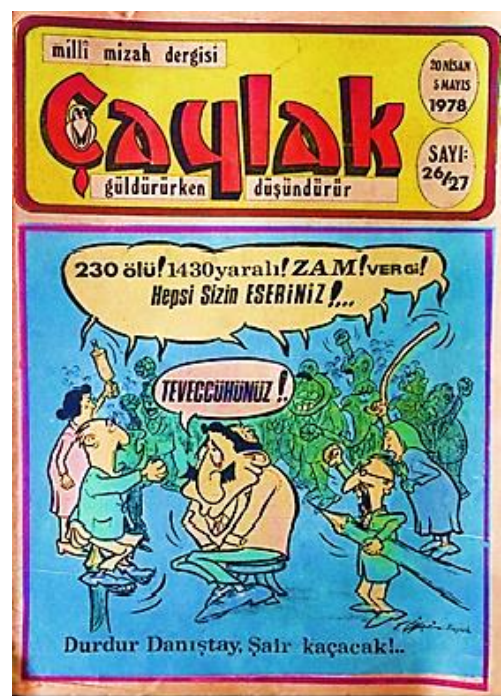

Resim 2: Çaylak Dergisi 26/27. sayı (1978)

Sahibi ve yazı işleri müdürü Selamet Bayhan, Genel Yayın Müdürü Uğur Tekin olmakla birlikte Seyyah-1 Fakir Evliya Çelebi müstear ismiyle Dilaver Cebeci, Enver Orhan, M. Sait Kıran, Haldun Seven, Hakan Poyraz, Hasan Gürpınar, Abdullah Manas, E. Cengiz Alpay, Selçuk Oksal, Serdar Sağlam, İsmet Keten, Halil Nejat Altındağ, Ali Yurtgezen, Şamil Elbeğ, Uğur Tekin, Tuncer Özbaykal, Vehip Sinan ve Erbay Kücet gibi isimler yazar ve çizerlik yapmıştır. 1977 yılının Nisan ayında yayımlanan 11. sayıdan itiba- 
ren de Türk mizahının önemli isimlerinden olan Nejat Uygur dergide yazmaya ve çizmeye başlamıştır. İdare yeri ilk olarak Ankara'nın Ulus ilçesinde bulunan ve bir zamanlar basım yayın için önemli bir merkez olan Rüzgarlı Sokak'ta bulunmakla birlikte daha sonra İstanbul'a taşınmıştır.

Derginin içeriğinde Türk mizah ustalarına yer verilmiş, karikatür ve fıkralar başta Bülent Ecevit olmak üzere dönemin siyasileri ve komünizm hicvedilmiştir. Dergide, Milliyetçi Hareket Partisinin Milliyetçi Cephe Hükümetlerinde ortağı olduğu siyasi partileri hicveden çizimlere de yer verilmiştir. Dergideki çizimlerde güncel konulara da yer verilmiş, kürtajdan memurlara verilecek katsayıya, erken seçimden kiracıların sıkıntılarına, TRT'den Cem Karaca'ya kadar o dönemde Türkiye gündeminde olan birçok konu işlenmiştir. Abdurrahim Karakoç, Ahmet Tevfik Ozan gibi isimlerin şiirleri neşredilmiş Türk milliyetçiliğinin Peyami Safa, Dündar Taşer gibi önemli kalemlerinin daha önce neşredilen yazılarına yer verilmiştir. Her ne kadar siyasî mizah dergisi olduğu ifade edilse de doktriner içerik de muhteva ettiği görülmektedir.

İlk sayısı 1976 yılının Haziran ayında yayımlanan, Çaylak dergisinin sunuş yazısında mizahın solun etkili bir propaganda aracı haline geldiği, Türk milliyetçilerinin mizah alanındaki eksikliği ve Çaylak'ın bu eksikliği dolduracağı ifade edilmiştir.

Sevinçliyiz...Millî değerlerden günümüze kadar epey yoksun kalmış mizah alanında, dergimizle artık biz de varız. Şartlanmış ya da cıvık bazı çevreler istedikleri kadar rahat at koşturamayacaklar bu alanda...

Hatırlatıyoruz...Mizah deyince çizgide ahlâksızlığı, yazıda şarlatanlığı anlayan kimseler dergimizi boş yere almasınlar...Aradıklarını bulamayacakları bir yana, gülerken düşünmek zorunda kalmaları zaten boş olan kafalarını ağritacaktır...

Eksikliklerimizi biliyoruz...Ama 'Başarmak için başlamak' gerektiği inancındayız. Başarmak deyince solun etkili propaganda silahı haline getirilen mizahı milliyetçi camianın hizmetine vermeyi anlıyoruz. Hem de bize yakışır şekilde kimseye hakaret etmeden sömürü edebiyatı yapmadan... (Çaylak Dergisi, 1976: 1). 
Derginin ilk sayısında "ümitsiz" ülküdaşlara yönelik bir serzenişte bulunulmakla birlikte, derginin ticari kaygılarla çıkarılmadığı belirtilmiş ve Türk milliyetçileri derginin yaşatılması için "görev başına" davet edilmiştir:

Böyle bir dergi çıkartmanın zorluklarını taktir ediyor musunuz, bilemiyoruz? Arkanızda yüklü bir sermaye, sizin bedava propagandanızı yapacak güçlü bir çevre olmayınca ve üstelik şimdiye kadar milliyetçilerin seslerinin duyurulmadığı bir alanda mücadele etmeğe kalkınca, inançsızlar arasında yapayalnız kalıveriyorsunuz.

Sizi şüpheyle karşılayanlar oluyor, devlet büyüklerini eğri büğrü çizmekle, kutsal değerlerle alay etmekle, şeyi şaparım deyince gülmekle, yattı-kalktı seks edebiyatı yapmakla bir mizah dergisinin satışı olur diyenler çıkıyor. Sizi bir dergi olarak yaşatmazlar, boş yere vaktinizi harcamayın nasihati veriyorlar. Hiç olmazsa büyük bir gazetenin ya da kuruluşun himayesine girin diyorlar, güldürmek yeter, düşündürmek ne olacakmış diye çıkışıyorlar...

Biz ise size güveniyoruz. Bu dergiyi ticarî maksatlarla değil, bu alanda var olan boşluğu doldurmak için çıkarıyoruz. Milliyetçilerin sesini duyuracak olan dergimiz, dergimizi yaşatacak olan sizlersiniz... Bedelini yatırarak en kısa zamanda abone olun, abone bulun.. İlk başta gazete bayilerine pek dağıtılmayacak olan dergimizi böylelikle kolayca takip edebileceksiniz. HAYDİ GÖREV BAŞINA (Çaylak Dergisi, 1976: 16).

Gerçekten dergi az sayıdaki idealist gencin çabalarıyla, sınırlı imkanlar ve kaynaklarla Rüzgarlı Sokak'ta bulunan 5-6 metrekarelik bir odadan idare edilmiş ve hazırlanmıştır. Derginin dağıtımı ise il ve ilçelerdeki gönüllülerle, tanıdık kitap ve gazeteciler ile gerçekleştirilmiş, toplanan dergi bedelleri satıldıktan sonra parası postalanarak elde edilmiştir (Çiftçi, 2010).

Ancak tüm imkânsızlıklara rağmen derginin 1977 yılının ocak ayında yayımlanan 8. sayısında Dikkat! Piyasada 50 bin adet Çaylak var ifadesinden de anlaşılacağı üzere dergi çok zor şartlarda çıkarılmasına ve dağıtılmasına rağmen o dönemdeki diğer ünlü mizah dergileri kadar tiraj yapmıştır. Derginin sunuş yazısında ..Sayenizde amatör Çaylak dünya basın tarihinde eşi görülmemiş bir şekilde okuyucu sayısını artırarak selvi gibi boy attı.. Ah bir de dağıtım problemini layıkıyla halledebilsek demek ki sosyete ve kapitalist dergilerin tepesinden bakaca$\breve{g} \imath z . .$. denilmiştir. Bu yazıda derginin dağıtım problemlerinin devam ettiği anlaşılmakla birlikte, derginin basım için ofsete verildiği, 
sayfa sayısının arttırıldığı, dergideki karikatürlerinin \%95'inin okuyucuya ait olduğu belirtilmiştir (Çaylak Dergisi, 1977: 1). Dergi zamanla daha renkli ve daha profesyonel şekilde çıkarılmaya başlanmıştır. Dergi çıkmaya başladıktan 1 yıl sonra ise tiraj 160 bine ulaşmiştır.

Dergiye ilginin artması ve belirli bir seviyeye ulaşmasıyla birlikte dernekleşme konusu gündeme gelmiştir. 1977 yılının mart ayında yayımlanan 10. sayısında Türk mizahına hizmet etmek ve yetenekli kişilere yardımcı olarak eğitmek ve teşvik etmek amacıyla Çaylak Karikatüristler Derneği'nin kurulduğu haber verilmiştir (Çaylak Dergisi, 1977: 2).

\subsection{Derginin Neşredildiği Dönemde Siyasi Ortam}

Çaylak dergisinin neşredildiği dönem (1976-1978); I. Milliyetçi Cephe Hükümetine (1975-1977), 1977 erken genel seçimlerine, genel seçimlerden sonra Bülent Ecevit'in güvensizlik oyu alana kadarki 30 günlük hükümetine ve II. Milliyetçi Cephe Hükümeti (19771978) dönemine denk gelmiştir. Bu dönem; Türkiye'de koalisyonların ve hükümet krizlerinin, ekonomik bunalımların olduğu, sokak olaylarının yaşandığı, silahlı sol örgütlerin eylemlerini artırdığı, siyasette üslup ve söylemin sertleştiği, parti liderlerine ve konvoylarına saldırılar düzenlendiği, işçi hareketinin canlı olduğu, Taksim'de "kanlı" 1 Mayısın yaşandığı, sol grupların bazı bölgelerde "kurtarılmış bölgeler" kurduğu, Maraş katliamı ve Sivas olaylarının gerçekleştiği, faili meçhul cinayetlerin işlendiği, PKK'nın kurulduğu, siyasal İslam' ın görünürlüğünün arttı̆̆ı, 12 Eylül 1980 darbesinin hemen öncesindeki dönemdir. 


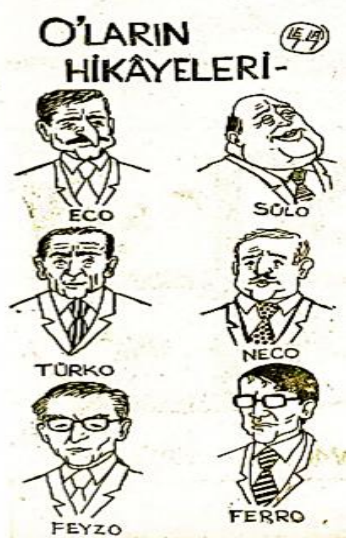

Resim 3. O'ların Hikayeleri (Çaylak Dergisi, 1976: 3)

Bu dönemde Türk siyasetinde önemli aktörler bulunmaktadır. Milliyetçi Hareket Partisi genel başkanı Alparslan Türkeş, Cumhuriyet Halk Partisi genel başkanı Bülent Ecevit, Adalet Partisi genel başkanı Süleyman Demirel, Milli Selamet Partisi'nin genel başkanı Necmettin Erbakan, Cumhuriyetçi Güven Partisi genel başkanı Turhan Feyzioğlu, Demokratik Partinin genel başkanı Ferruh Bozbeyli'dir.

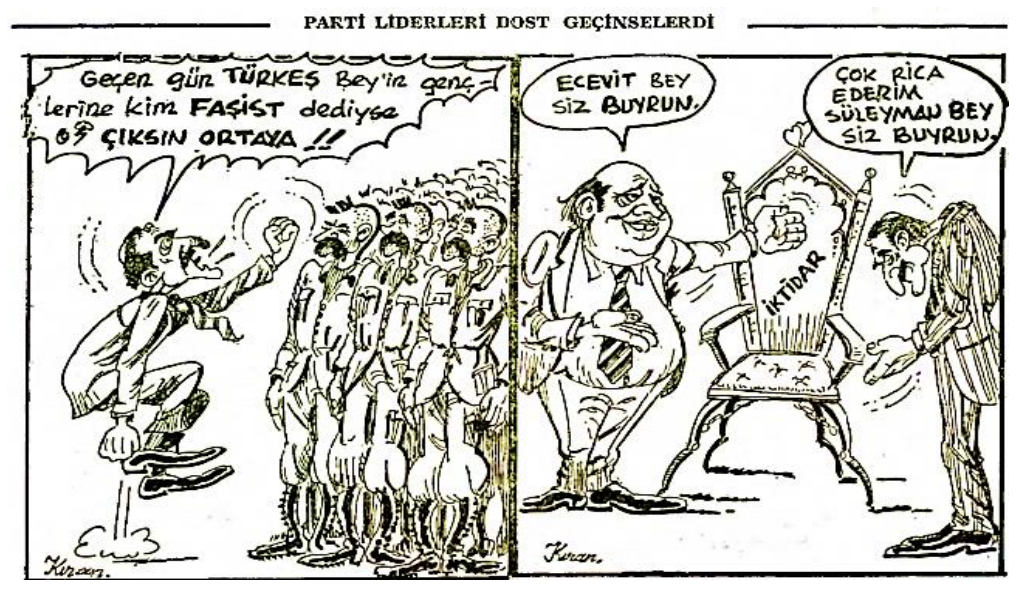

Resim 4. Parti Liderleri Dost Geçinselerdi (Çaylak Dergisi, 1976: 3) 


\subsection{Cumhuriyet Halk Partisine Yönelik Çizimler}

Çaylak dergisinden en çok nasibini alan Cumhuriyet Halk Partisi ve Bülent Ecevit olmuştur. Ecevit' in en büyük amacının iktidar olmak olduğu, kendini çok güçlü bir siyasi figür sandığı, kolej mezunu olmasının halk çocuğu olmakla bağdaşmayacağı gibi söylemlerde bulunulmuştur.

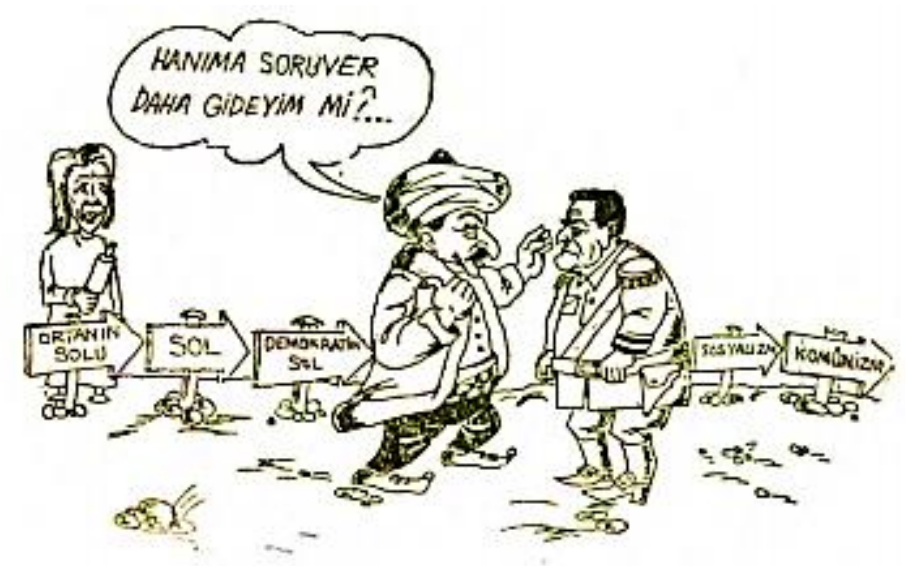

Resim 5. (Çaylak Dergisi, 1976:16)

Günümüzde de yaşanan "Yeni" CHP tartışmalarının 1970'li yıllarda da kamuoyunu meşgul etmiş, Çaylak' ta "Yeni CHP'nin" tüzügünden programına kadar değiştiği, Atatürk'ün 1srarla üzerinde durduğu 6 oktan birisi olan milliyetçiliği ihmal ettiği ifade edilmiştir. CHP'nin Atatürk'ten sonra İsmet İnönü ile birlikte değişmeye başladığı ve Ecevit ile birlikte sola daha fazla kaydığı hicvedilmiştir. 


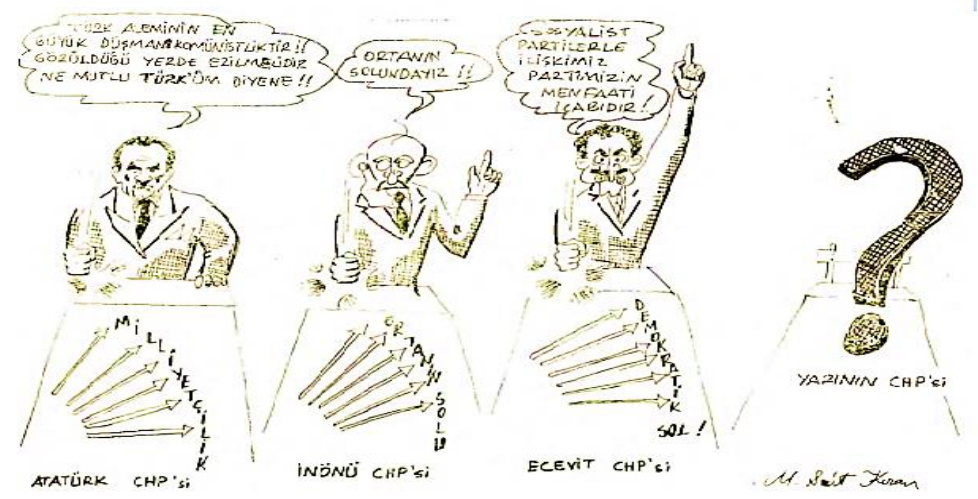

Resim 6. (Çaylak Dergisi, 1976:3)

\subsection{Dergide Anti Komünist Çizimler}

Dergi komünizm karşıtı bir yayın politikası gütmekle birlikte ilk sayısından 8. sayısına kadar kapağında Bu mizah dergisi maatteessüf! Sola açık değildir... yazmaktadır. 3'ün sayısının sunuşunda ise gülerken düşünecek, komünizme ve kapitalizme verdiğimiz cevaplarla bir nebze olsun ferahlayacaksını denilerek komünizm ve kapitalizm karşıtı içerik üretildiği, memleket ve dünya meselelerinin ele alındığı ifade edilmiştir.

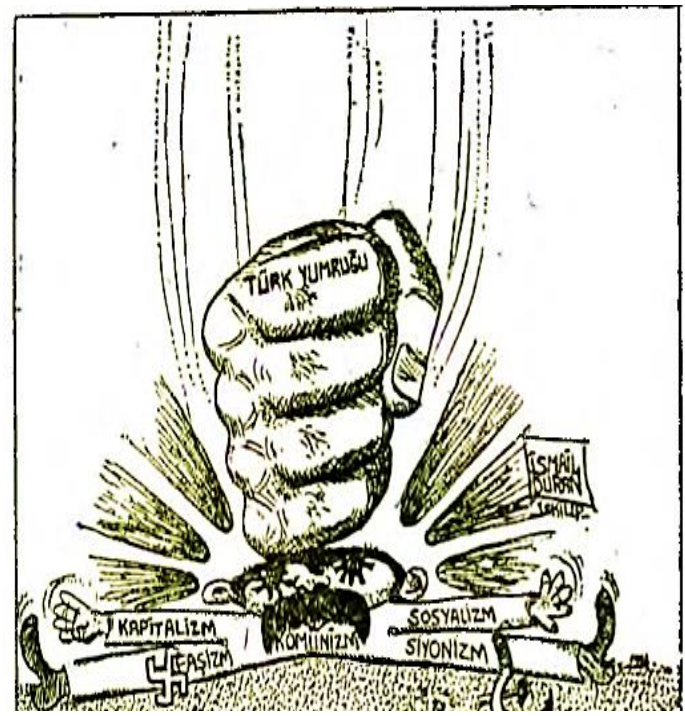

Resim 7. Yarınlarda (Çaylak Dergisi, 1976: 5) 
Derginin 3'üncü sayısının arka kapağında Türkiye' nin Sovyet Rusya, Çin, Amerika, İngiltere, Fransa, Masonluk ve Yahudiler ve diğer emperyalist devletler tarafından yıkılmaya çalışıldığı resmedilmiştir. Her ne kadar derginin ana teması antik-komünist bir söylem muhteva etse de Türk milliyetçilerinin Türkiye Cumhuriyeti'ne yönelik tehdit algısını göstermesi bakımından önemlidir.

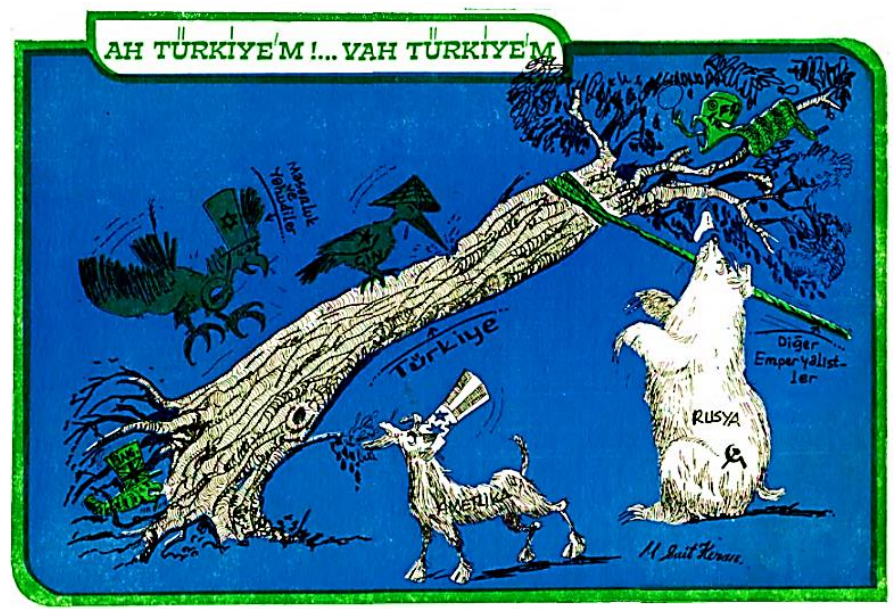

Resim 8. Ah Türkiyem !.. Vah Türkiyem (Çaylak Dergisi, 1976: 20)

\subsection{Akıncılara Yönelik Çizimler}

İslamcı gençlik 1969 yılı itibariyle İslamcı bir görünüm kazanan Milli Türk Talebe Birliği (MTTB), Milli Nizam Partisi ve ardılı Milli Selamet Partisi'nin gençlik örgütlenmeleri çerçevesinde teşkilatlanmıştır. 1970'li yıllarda Akıncı ismi İslamcı gençleri ifade etmek için kullanılmış olup 1975 yılında da İslamcı gençliğin örgütlendiği Akıncılar Derneği kurulmuştur. Akıncılar milliyetçi ve sosyalist hareketlerden bağımsız üçüncü bir yol olarak ortaya çıkmış ve sokak olaylarının dışında durmayı hedeflemiştir. Ancak yeni bir yol olarak kendini kabul ettirmek ve siyasal alanda ortaya çıkmak kolay olmamış, Akıncı gençlik de sokak olaylarına karışmıştır. Bu bağlamda Akıncılar Ülkücü hareketle de karşı karşıya gelmiştir. İlk olarak 1976 yılında Malatya'da ve Erzurum Atatürk Üniversitesinde 
bir takım olaylar yaşanmış, İslamcı gençler Ülkücülerin derslere girmesini engellemiş, "faşist" olmakla itham edilmiş, Ülkücülerin CIA tarafından teşkilatlandırıldığı iddia edilmiştir (Zengin, 2017: 175). Çaylak dergisinde "solun ihanet derecesine varan davranışları" ile birlikte "ertelenmiş kavga" da konu olmuş, Akıncılara yönelik hicivler yer bulmuştur.

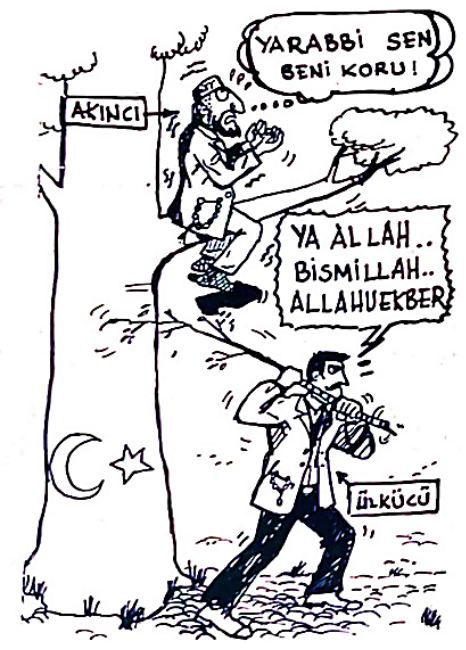

Resim 9. (Çaylak Dergisi, 1977: 16)

Dergide yazı ve şiirleriyle yer alan Abdurrahim Karakoç derginin 11. sayısında Akıncıları tarif ederken şunları söylemiştir:

Kendi yapmaları lazım geleni Allah'a havale edip Allah'ın "yapmayınız" diye men ettiği şeyleri yapan, miskin korkak, iftiracı ve övünen besleme sürüsüne benzetiyorum. Alpaslan'a, Kılıçaslan'a, Selahattin Eyyübiye, Akça Kocaya, Rahman Gaziye, Evranos Beye, Malkoçoğlu'na benzetirsem bana kim gülmez? (Kapanoğlu, 1977: 11). 
Akıncılara ithafen yazdığı bir şiirin bir bölümü ise şu şekildedir:

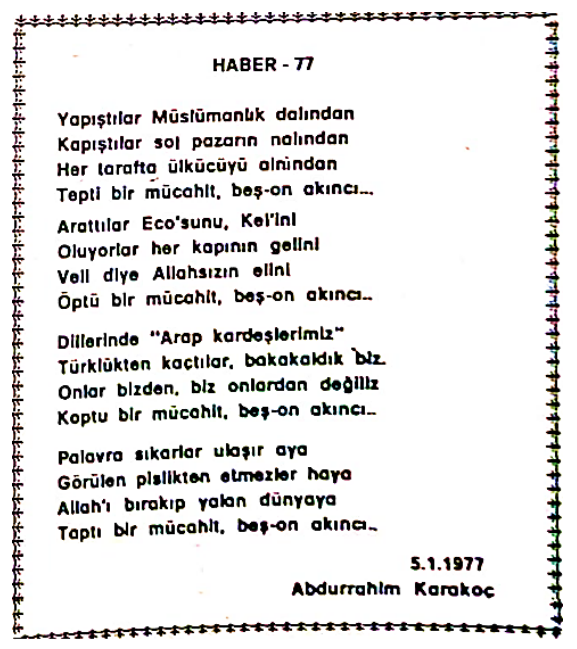

Resim 10. (Çaylak Dergisi, 1977: 11)

Türk milliyetçilerinin İslamcıların tutumlarından rahatsız oldukları görülmekle birlikte Müslümanlığa ve İslam dinine bakış açılarına eleştiriler getirilmiştir. Bu bağlamda siyasal alanda İslamcı

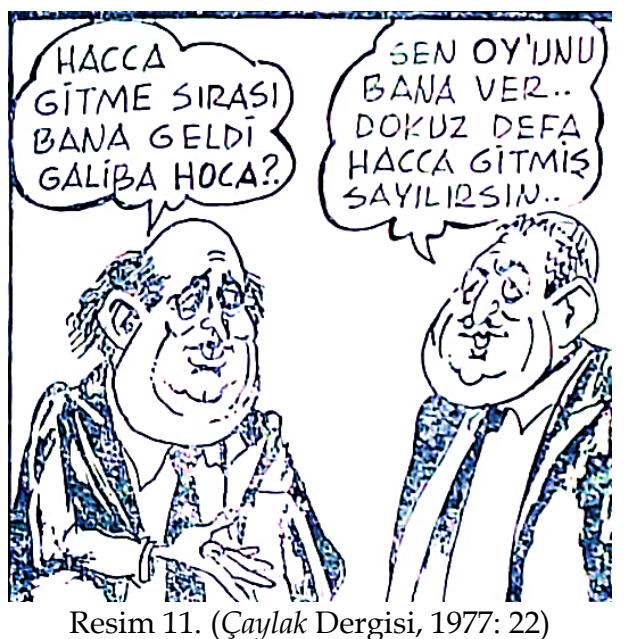


hareketi temsil eden ve Milli Selamet Partisi'nin genel başkanı olan Necmettin Erbakan da hicvedilmiştir.

\subsection{Dünya'da Gerçekleşen Hadiseler}

Dergide dünyada gerçekleşen hadiselere de kayıtsız kalınmamış, her sayıda belirli başlı meseleler çizimlerle ve yazılarla ele alınmıştır. Örneğin Kamboçya'da Kızıl Kmerler hareketi tarafından Çam Müslümanı ve Vietnam asıllı Kamboçyalılara yönelik gerçekleştirilen soykırıma dair de çizimler bulunmaktadır. Kızıl Kmerler Pol Pot önderliğindeki Maocu bir hareket olup 1975-1979 yılları arasında Kamboçya' da iktidarı ele geçirmiş ve sınıfsız bir tarım toplumu yaratmak maksadıyla katliamlar gerçekleştirmiş ve yaklaşık 2 milyon kişinin ölümüne sebep olmuşlardır (https://www.bbc. com, 2018).
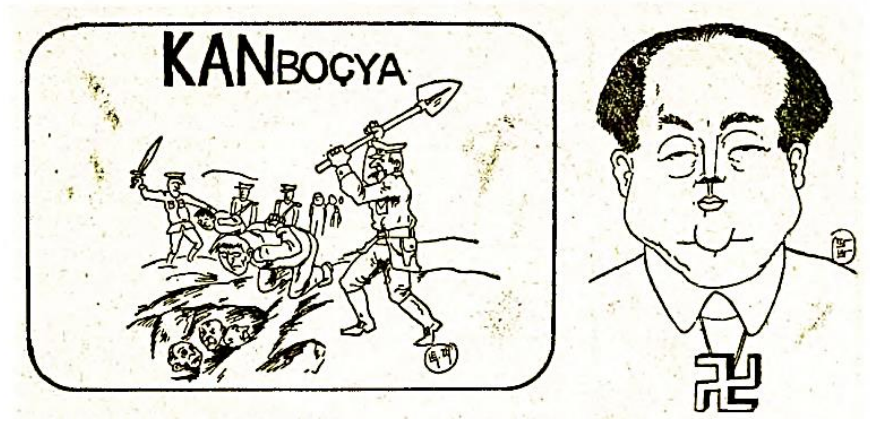

Resim 12. Kanboçya (Çaylak Dergisi, 1976: 5)

Çin Komünist Partisi' nin ve Çin Halk Cumhuriyeti' nin kurucusu Mao Zedong'un ölümü de Çaylak dergisinde birçok çizimin konusu olmuştur. Mao'nun Türkistan Türklerini katlettiği, işçi sınıfı adına işçileri katlettiği, partide rakiplerini katlettiği ifade edilmiştir. Derginin 5. sayısının arka kapağında Mao'nun ölümüne yer verilmiştir. 


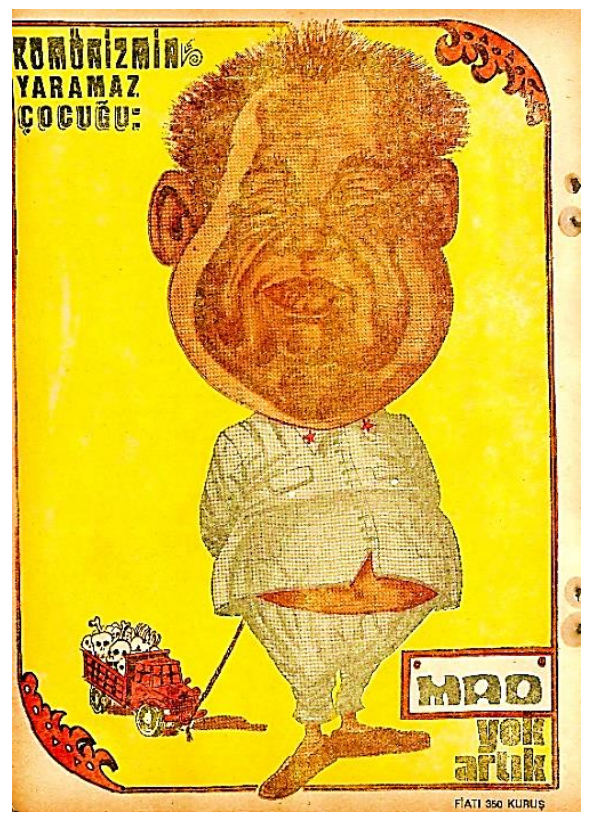

Resim 13. Komünizmin Yaramaz Çocuğu (Çaylak Dergisi, 1976: 20)

"Mavi vatanda" gerçekleştirilen sismik araştırma çalışmalarının geçmişi 1970'li yıllara kadar uzanmaktadır. Bu yıllarda yapılan araştırmalarda Hora isimli araştırma gemisi kullanılmıştır. İkinci Dünya Savaşı sonrasında Almanya tarafından Türkiye'ye hibe edilen Hora, özellikle 1974 yılında gerçekleştirilen Kıbrıs Barış Harekatı'ndan sonraki süreçte aktif şekilde kullanılmaya başlanmıştır. Hora gemisinin faaliyetleri Yunanistan' da ciddi rahatsızlık yaratmış, Türkiye'ye nota verilmiş ve 1976 yılında savaşın eşiğine gelinmiştir (https:/ /www.milliyet.com.tr, 2011). Çaylak dergisi bu meseleyi de ele almıştır. 


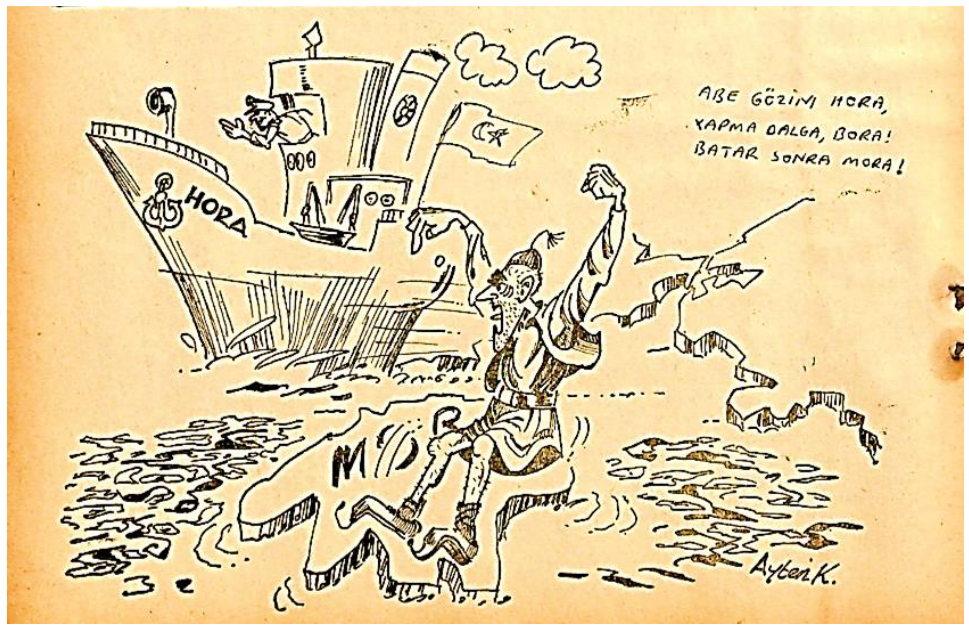

Resim 14. Hora (Çaylak Dergisi, 1976: 2)

\subsection{Doktriner İçerik}

Alparslan Türkeş tarafından 9 Işık umdeleri etrafında bir kalkınma modeli olarak ortaya konan ve özellikle 1965-1971 yılları arasinda ifadesini bulan "milliyetçi toplumcu" söylem de dergide yerini almıştır. Milliyetçi toplumcu söylem çerçevesinde Türk milletini işçi, köylü, esnaf, memur, serbest meslek sahibi ve işverenden müteşekkil altı farklı sosyal dilim üzerinden ele alarak ekonomik ve sosyal kalkınmayı hedefleyen bir model ortaya konulmuştur. Liberal kapitalizm ve Marksizme eleştiriler getirerek alternatif ve sistematik bir kalkınma modeli ortaya konulmaya çalışılmıştır.

Çaylak dergisinde Genç Korkut mahlasıyla Halil Nejat Altındağ isimli şair tarafından milliyetçi toplumcu söylemde Türk milletinin oluşturan 6 farklı sosyal dilim olan işçi, köylü, esnaf, memur, serbest meslek sahibi ve işveren üzerine destanlar yazılmıştır. Genç Korkut 5. sayıda altı sosyal dilime dair destanlar yazacağının haberini şu şekilde vermiştir:

Kıvançta ve tasada ortak asırların kazandırdığı şuurla kaynaşmış bir milletiz bir.. Ne halklar vardır bizde ne de sınıflar.. Birbiriyle içiçe yaşayan 6 sosyal dilim var. İşçi, köylü, işveren, esnaf, memur, serbest meslek sahibi Bundan böyle her sayıda bu dilimlerin destanını vereceğiz size (Çaylak Dergisi, 1976: 15). 
Bu kapsamda 5. sayıda "İşçi Destanı", 6. sayıda "İşveren Destanı", 7. sayıda "Esnaf Destanı", 8. sayıda "Köylü Destanı", 9. sayıda "Serbest Meslek Destanı", 10. sayıda "Memur Destanına" yer vermiştir. Bu şiirlerde söylem çerçevesinde geliştirilen ifadeler şiirlere yedirilmiştir. 10. sayıda yer alan Memur Destanı'nda yer alan satırların bir kısmı şu şekildedir:

Kısaca altı sosyal dilim budur arkadaşlarım,

Bu yolda gönül vermiş yiğitleri kutlarım!

$\mathrm{Bu}$ yol ki fakirlerin kanla çizdiği yoldur,

Bu yol şehitlerimin nurlarıyla doludur.

Başladığımız işi, Türk gibi bitirelim

Altı sosyal dilimi biz gerçekleştirelim. (Çaylak Dergisi, 1977: 27).

Daha sonra Halil Nejat Altındağ tarafından kaleme alınan bu şiirler Çaylak Yayınlarınca "Kara Eşek Destanı" adı altında bir araya getirilerek şiir kitabı olarak yayımlanmıştır. Çaylak Yayınları tarafından Çaylak dergisinde çizilen bazı karikatürler de kitaplaştırılmiştır.

\subsection{Diş Türkler}

Türk milliyetçiliğinin en temel meselelerinden birisini diş Türkler oluşturmaktadır. Derginin neşredildiği dönem nazara alındığında bugün çoğu muhtar ve bağımsız olan Türk devletlerinin SSCB bünyesinde "esir" olduğunu görmekteyiz. Alparslan Türkeş'in şu ifadeleri Türk milliyetçilerinin dış Türklere dair görüşlerini özetler niteliktedir:

Dünyanın neresinde Türk varsa, Türk milliyetçilerinin ilgileri içindedir. Dış Türkler için elden be gelirse yapmayı Türk milliyetçilerinin boynuna borç sayarız. Fakat bunun için şartlarımız vardır. Baş şart Türkiye'nin tehlikeye sokulmamasıdır. Çünkü bütün dış Türklerin kurtuluşu Türkiye' nin varlığına bağlıdır...Dış Türklerin kurtuluşunu, hür olmalarını istemek bizim meşru hakkımızdır (Türkeş, 1975: 82). 
Nitekim dış Türkler meselesine Çaylak dergisinde de büyük yer ayrılmıştır.

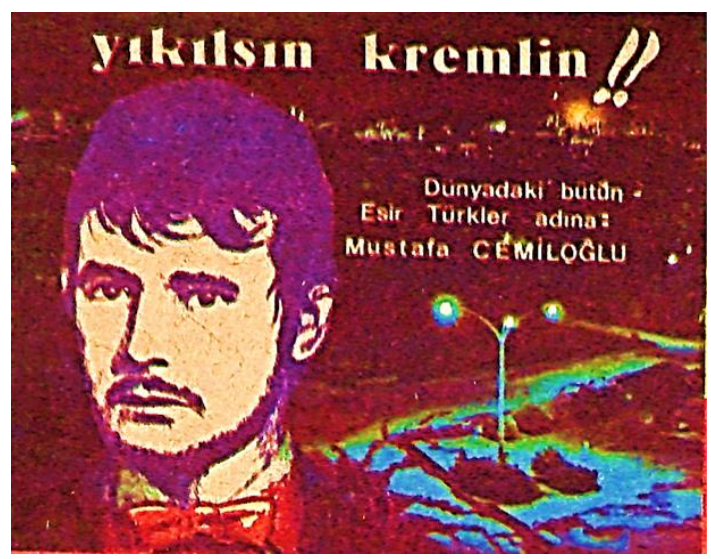

Resim 15. Mustafa CEMILOĞLU (Çaylak Dergisi, 1977: 16)

Derginin 11. sayısından itibaren Enver Orhan ve Taner Çiftçi tarafından "Esir Köy" başlığı altında "esir soydaşlarımızın komedi dramını aksettirmeye çalışalım" denilerek Dış Türklere yönelik çizimler yer almıştır. Derginin 14'üncü sayısında "Çaylak Babayasası" başlığı altında Çaylak dergisinin "Esir Türkleri tanımayanları, esir Türkleri her nedense görmezlikten gelenleri her sayıda teşhir edeceğine yemin eder." ifadesine ver yerilmiştir (Çaylak Dergisi, 1977: 2). 


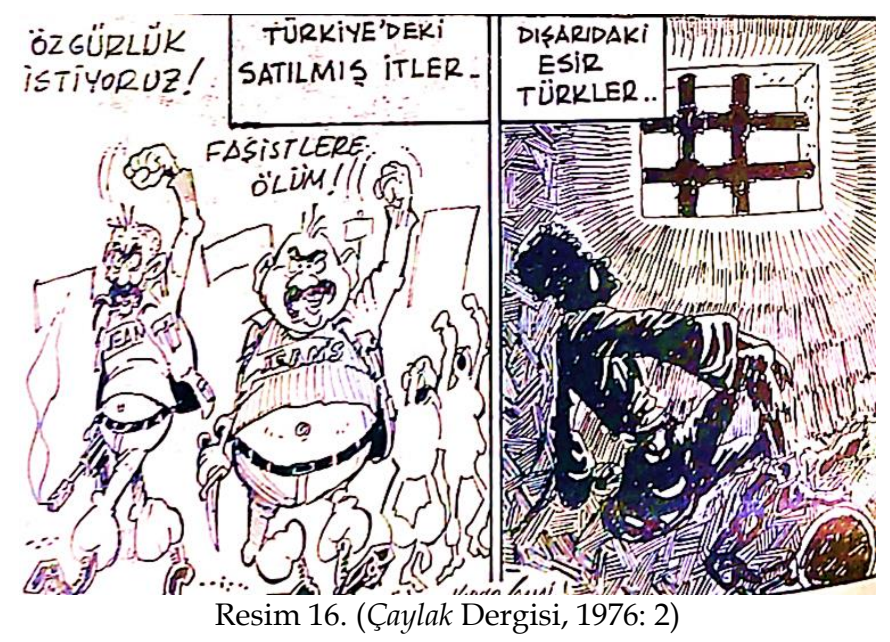

\section{8. Ülkücülere Yönelik İthamların Ele Alınışı}

Derginin yayımlandığı yıllar Türkiye' de sokak olaylarının yaşandığı, "kavga günlerinin" şiddetlenerek devam ettiği döneme rastlamaktadır. Bu dönemde kaos ve anarşi ortamı kanıksanmış, şiddet olayları kitleselleşmiş, toplumsal anlamda bir kutuplaşma yaşanmaya başlanmıştır (Uzun, 2021: 1093). Özellikle sol çevrelerce yaşananların müsebbibi Türk milliyetçileri olarak gösterilmiş ve eli silahlı sol militanlarca Ülkücülere yönelik olarak "faşist", "1rkçı", "gerici", "yobaz", "komando" gibi ithamlarla bulunulmuştur. Bahse konu ithamlar da dergide yer bulmuş ve bir çok çizimde yerilmiştir. 


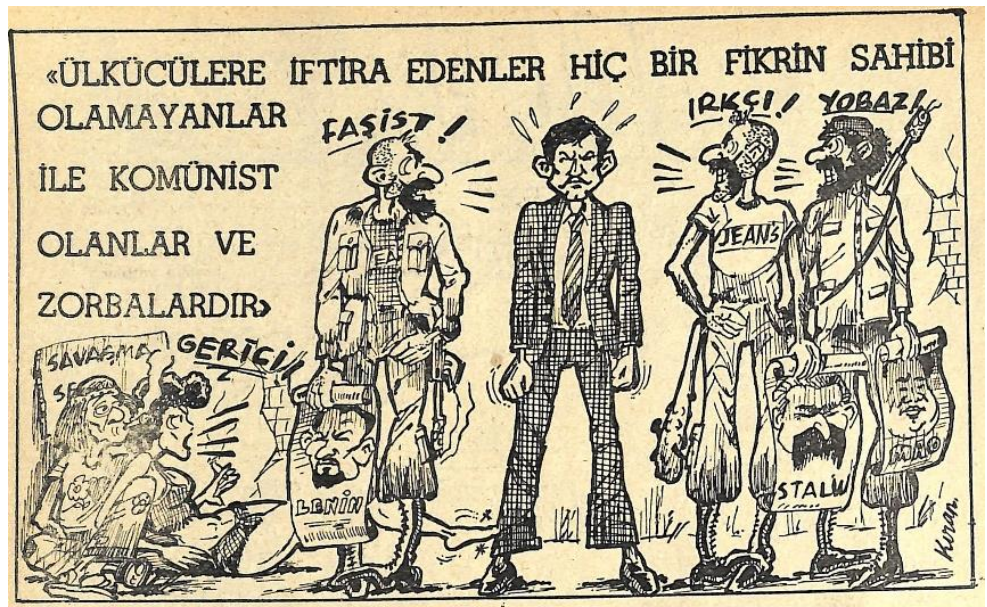

Resim 17. (Çaylak Dergisi, S.5, 1976: 15)

\subsection{Ahlaki Hassasiyetlere Yönelik Çizimler}

Çaylak dergisi içeriğinde müstehcenliğe yer verilmemiştir. Ülkücü geleneğin "İslam ahlak ve faziletini" esas alan söylemi böyle bir anlayışa cevaz vermemiştir. Nitekim Çaylak dergisinden tam 30 yıl evvel 1946 yılında kurulan Türk Kültür Ocağı yayımladığı bir beyannamede müstehcen neşriyatı telin ve takbih etmiştir. Türk milletinin ahlak ve mukaddesatını, ahlak ve aile müessesini yıkıcı neşriyatın başının ezilmesi gerektiği ifade edilmiştir (Darendelioğlu, 1968: 156). Bu husus Çaylak dergisinin birinci sayısında da dile getirilmiş ve şu şekilde ifadesini bulmuştur :

...Türk ailesinin yaşantısı, Türk toplumunun gelenek ve görenekleri çă̆ dışıdır onlar için... Devrim nikâhı adı altında olanca edepsizlik yapmak, şerefsiz ve inançsız yaşamak da ilericilik!.. Türk anasını, Türk kızını basit bir dişi haline getirmek de zamanelik... (Çaylak Dergisi, 1976: 8). 
Ayrıca dergide alkolün zararları hakkında da çizimlere yer verilmiştir. Temel Temürcü tarafından derginin 12. sayısında kaleme alınan bir şiir şu şekildedir:

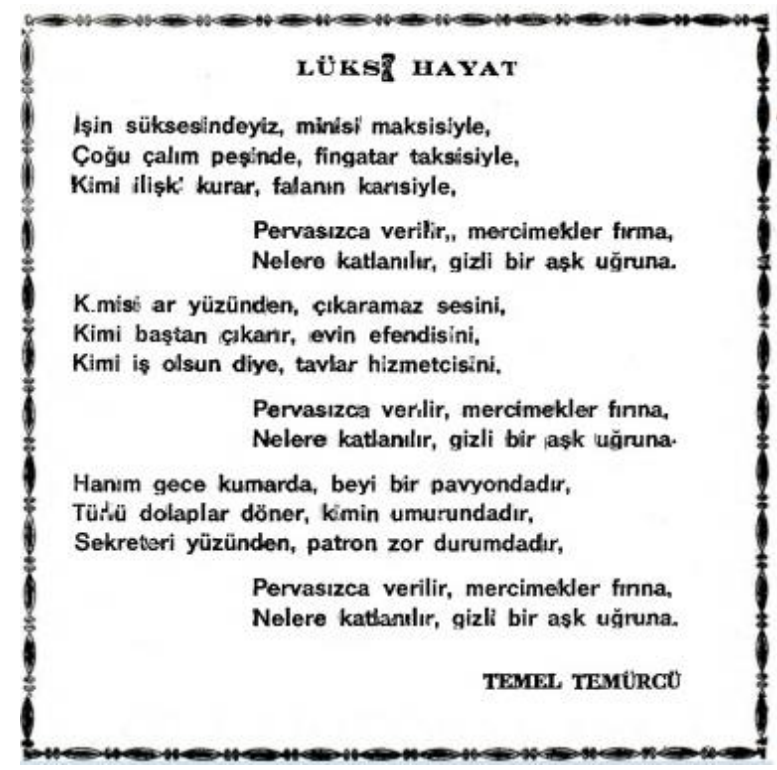

Resim 18: Lüks Hayat (Çaylak Dergisi, S.3, 1976: 7)

\subsection{Nejat Uygur}

Nejat Uygur (1927-2013) Türk tiyatrosunun, Türk mizahının önde gelen isimlerindendir. 1949 yılında Nejat Uygur tiyatrosunu kurarak profesyonel tiyatro hayatına başlamış, tuluat tiyatrosunun en güzel örneklerini vermiş, Anadolu'nun birçok yerinde sahneye çıkmış, geniş kitleler tarafından benimsenmiş, birçok ödüle layık görülmüştür. 2013 yılında hayatını kaybetmiştir. Çaylak dergisinin 1977 yılının Mart ayında yayımlanan 10'uncu sayısında Nejat Uygur'un artık Çaylak'ta olacağı müjdelenmiş, nisan ayında yayımlanan 11. sayıdan itibaren Çaylak dergisinde yer almaya başlamıştır. Derginin 12. sayısında yapılan röportajda Çaylak dergisinin tarafsız olmadığının belirtilmesi üzerine Uygur Benim tarafsız olduğumu kim 
söyledi ki. Hak için, haklının yanında, daha güzel günlerin kavgasını verenlerin yanında ve safındayım ben... demiştir (Çaylak Dergisi, 1977: 15).

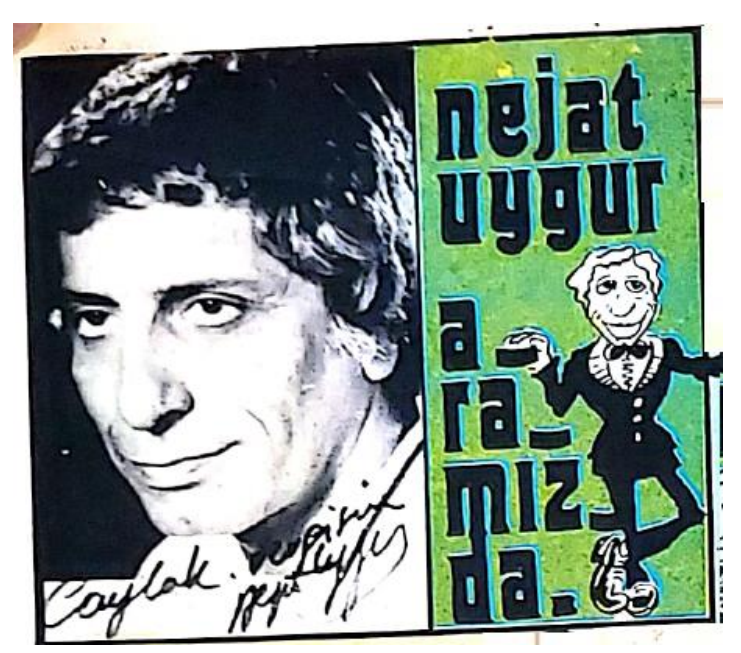

Resim 19: Nejat Uygur (Çaylak Dergisi, S.11, 1977: 8)

\section{SONUÇ}

1980 öncesi döneme bakıldığında Türk milliyetçilerinin tüm imkânsızlıklara rağmen Büyük Ülkü dergisinden, Kürt kökenli vatandaşlara yönelik Kon dergisine; dış Türkler hakkında yayınlar yapan Birlik dergisinden Devlet dergisine kadar farklı içeriklere sahip birçok dergi neşrettiği, Türkiye' deki milliyetçi neşriyatın üretken ve çeşitli olduğu görülmektedir. Çaylak dergisi de bu çeşitlilik içerisinde önemli bir yere sahiptir.

Çaylak dergisi 1976-1978 yılları arasında Türk milliyetçilerinin daha önce yayın yapmadığı bir alanda, az sayıdaki idealist gencin çabalarıyla, sınırlı imkanlar ve kaynaklarla çıkarılan bir mizah dergisidir. Amacı "inandığı ve bağlı olduğu davanın mizah alanında sesini duyurmak" olması sebebiyle dergide genel itibariyle Ülkücü hareketin ideolojik sınırları çerçevesinde içerik üretilmiştir. Dergi 
içeriğine bakıldığında; dış Türklerden, milliyetçi-toplumcu düzene, Amerikan emperyalizminden anti-komünizme kadar birçok konunun ele alındığı görülmektedir.

Dergi içeriğinde Ülkücü hareketin doktriner düşüncesi ve hassasiyetlerinin yanında 12 Eylül 1980 askeri darbesinden önceki "kavga günlerinin" izleri bulunmakta, koalisyon dönemlerinin ve siyasi kargaşanın dergiye konu olduğu görülmektedir. Siyasi kargaşa ortamına rağmen derginin hemen her sayısında dönemin siyasal aktörlerine yönelik hicivlere yer verilmiş, karikatürlerde mizah ustalıkla kullanılmıştır.

“Türk milliyetçiliği mizah üretebilir mi?" sorusuna cevap aranacak olursa; Türk milliyetçilerinin daha önce yayın yapmadığı bir alana el atmış olması, ideolojik hassasiyetlerden mülhem içerik üretilmeye çalışılması, dönemin basım yayın teknikleri kullanılarak her sayının bir öncekine nazaran daha profesyonelce çıkarılmış olması, derginin 27 sayı çıartılarak belirli bir süreklilik yakalaması ve her ne kadar derginin ilk sayılarında "ümitsiz ülküdaşlara" sitem edilmiş olsa da tirajının 60 binlere ulaşması mizahın Türk milliyetçilerince Çaylak dergisi özelinde maharetle kullanılabildiğini göstermektedir.

Ayrıca derginin yazar ve çizer kadrosuna okuyucuların da dahil edilerek genç kabiliyetlerin teşvik edilmesi, dergide çizilen bazı karikatürlerin kitaplaştırılarak yeniden neşredilmesi Türk milliyetçisi okurların mizah üreten bir neşriyat hususunda talepkar olduğu göstermektedir. Türk milliyetçilerinin Çaylak dergisi tecrübesinin hatırlamasının ve günümüzün basım ve yayın tekniklerini kullanarak yeniden mizahi içerik üretmeye başlamasının Türk milliyetçiliğine, Türk siyasal hayatına ve Türk mizahına ciddi katkılar sunacağı değerlendirilmektedir. 


\section{KAYNAKÇA}

Akpınar, H. (2005). Kurtların Kardeşliği CKMP'den MHP'ye (19652005). İstanbul: Birharf Yayınları.

Alay, O. (2019). "Mizah Kavramı ve Mizahın Tarihsel Süreci”. Türk Dili Dergisi. 116 (808): 22-30

BBC. (2018). “Kamboçya'da Kızıl Kmer liderleri ilk kez soykırımdan suçlu bulundu". https://www.bbc.com/turkce/haberlerdunya-46234432. (21.08.21)

Boz, U. (2014). “Toplumsal Eleştiri Yöntemi Olarak Mizah ve Türk Mizahı: Yeni Medyadan Bahattin Örneği". Akdeniz Üniversitesi İletişim Fakültesi Dergisi. (21): 143-159

Çavdar, O. (2018). Siyasal İletişim Aracı Olarak Gazetelerde Politik Mizah ve Karikatür: 2014 Cumhurbaşkanlığı Seçimleri Örneği. Erzurum: Atatürk Üniversitesi Sosyal Bilimler Enstitüsü.

Çaylak Dergisi Sayıları (Metin içerisinde gösterilmiştir).

Çiftçi, T. (2010). "Selçuk Oksal Uçmağa Vardı" https:/ / www.turkyurdu.com.tr/yazar-yazi.php?id=1911 (11.08.2021)

Darendelioğlu, İ. E. (1968). Türkiye'de Milliyetçilik Hareketleri. İstanbul: Toker Yayınları.

Demirkol, G. (2017). “Çaylak Tevfik' in Çaylaklık Eseri: Asır Mizah Dergisi (1870)”. Erciyes İletişim Dergisi. 5 (2): 20-28

Güder, F. Z. (2012). Siyasal İletişimde Politik Mizah: Örnek Çalışma: Semih Balcıoğlu'nun Güle Güle İstanbul Karikatürlerinin İncelenmesi. İstanbul: İstanbul Üniversitesi Sosyal Bilimler Enstitüsü.

http:/ / www.tdk.gov.tr (11.08.2021)

https:/ / islamansiklopedisi.org.tr/mizah (11.08.2021)

Kapanoğlu, S. (1977). “Abdurrahim Karakoç ile Sohbet”. Çaylak Dergisi (11): 11.

K1liçer, G. S. (2005). Karagöz (1930-1938) Siyasi, Mizahi Bir Halk Gazetesi. Ankara: Ankara Üniversitesi Sosyal Bilimler Enstitüsü. 
Milliyet. (2011). “Nostaljik Kriz". https://www.milliyet.com.tr/gundem/nostaljik-kriz-1440583. (21.08.21).

Öngören, F. (1998). Cumhuriyetin 75. Yllında Türk Mizahı ve Hicvi. İstanbul: Türkiye İş Bankası Kültür Yayınları.

Sarı, G. (2017). “Penguen, Grrgır, Mizah Dergilerinin Ömrü ve Ölümü." https://journo.com.tr/penguen-girgir-mizah-dergileri. (E.T: 18.08.2021).

Turhanlı, Ö. (2019). Türk Siyasal Hayatındaki Gelişmelerin Politik Mizaha Yansimasi: 'Akbaba Dergisi' Örneği (1922-1977). Afyon: Kocatepe Üniversitesi Sosyal Bilimler Enstitüsü.

Türk, T. (2015). Türk Siyasal Hayatında Politik Mizah. İstanbul: Marmara Üniversitesi Sosyal Bilimler Enstitüsü.

Türkeş, A. (1975). Türkiyénin Meseleleri. İstanbul: Kutluğ Yayınları.

Uzun, T. (2020). “Türk Siyasal Hayatında Milliyetçi Hareket Partisi". Tevfik Erdem (ed.) Milliyetçilik. İstanbul: Otorite Yayınlar1. 329-351

Veren, E. (2018), “IX. Yüzyıl Öncesi Türk Kültürel Belleğinde Mizahin İzleri". Millî Folklor Dergisi. (119): 114-126.

Zengin, E. (2021). Akıncılar Hareketi. İstanbul: İletişim Yayınları.

ETİK: Bu makale, yazarın başvuru aşamasındaki beyanına göre; araştırma ve yayın etiğine uygun olarak hazırlanmıştır.

ETHIC: This article has been prepared in accordance with research and publication ethics, according to the author's statement at the application stage.

ÇIKAR ÇATIŞMASI VE FİNANSAL KATKI BEYANI: Yazarın başvuru aşamasındaki beyanına göre; çalışmanın tarafsızlığı ile ilgili bilinmesi gereken bir mali katkı veya diğer çıkar çatışma ihtimali (potansiyeli) ve ilişki alanı yoktur.

CONFLICT OF INTEREST AND FINANCIAL CONTRIBUTION DECLARATION: According to the author's statement at the application stage; There is no financial contribution or other conflict of interest possibility (potential) and relationship area that should be known about the objectivity of the study. 


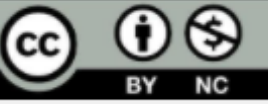

Bu eser Creative Commons Atıf-GayriTicari 4.0 Uluslararası Lisansı ile lisanslanmıştır.

This work is licensed under a Creative Commons Attribution-NonCommercial 4.0 International License. 